\title{
GLACIOCHEMICAL INVESTIGATIONS AS A TOOL FOR DETERMINING THE SPATIAL AND SEASONAL VARIATION OF SNOW ACCUMULATION IN THE CENTRAL KARAKORAM, NORTHERN PAKISTAN
}

\author{
by \\ Cameron P. Wake* \\ (Wilfrid Laurier University, Waterloo, Ontario N2L 3C5, Canada)
}

\section{ABSTRACT}

Between 70 and $80 \%$ of the total annual run-off from the Upper Indus Basin originates from heavy snowfall and glacierized basins at elevations greater than $3500 \mathrm{~m}$ a.s.1. However, very little is known concerning the mountainous headwaters of the Indus. This is especially true with respect to the amount of snowfall in the major source area, the high Karakoram. Recent studies of high-altitude alpine glaciers indicate that geochemical dating techniques can accurately and confidently identify seasonal and annual stratigraphy within snow pits and ice cores, and thus can be used to determine the seasonal and annual rate of snow accumulation. In addition, chemical records can usually be employed to determine sources of precipitation. Six snow pits, each 5-10 $\mathrm{m}$ deep, were investigated in the accumulation zones of the Biafo and Khurdopin Glacier basins. Both accumulation zones are characterized by broad, open basins separated by steep, narrow ridges in which direct precipitation is the dominant form of nourishment. Seasonal stratigraphy is delineated through an analysis of the seasonal variation in the chemical and physical characteristics of the snow-pack. Annual snow accumulation in the Biafo Glacier basin ranges from 0.9 to $1.9 \mathrm{~m}$ water equivalent; maximum accumulation occurs in the elevation band $4900-5400 \mathrm{~m}$ a.s.l. Roughly one-third of this snow accumulation occurs during the summer.

\section{INTRODUCTION}

Pakistan depends heavily upon the waters of the Upper Indus Basin (UIB) for power generation, irrigation, and water supply. Between 70 and $80 \%$ of the total annual run-off from the UIB originates from heavy snowfall and glacierized basins at elevations greater than $3500 \mathrm{~m}$ a.s.l Glacier basins are concentrated along the northern edge of the watershed, especially in the Karakoram Himalaya, and this mountain range contains approximately $15000 \mathrm{~km}^{2}$ of perennial snow and ice (Mercer, 1975). The major role which the Karakoram plays in the hydrology of the UIB draws attention to the snow and ice conditions in this mountain range.

Little is known concerning the mountainous headwaters of the Indus. A concerted research effort concentrating on the glacial hydrology of the UIB was begun in 1985, as part of the Snow and Ice Hydrology Project. The work presented in this paper is concerned with estimating precipitation inputs into the region. Most of the precipitation in the Karakoram Range occurs at elevations greater than $3500 \mathrm{~m}$ (Hewitt, 1986). It is this precipitation, in the form of snow, that creates the only large moisture surplus for the region. However, precipitation records for

*Currently with the Glacier Research Group, Institute for the Study of Earth, Oceans and Space, University of New Hampshire, Durham, NH 03824, U.S.A. the UIB come from weather stations which lie well below $3500 \mathrm{~m}$, mostly in semi-arid and valley locations. The stations are in the main towns of the region, and subject to the topoclimatic effects of valley wind systems (Butz and Hewitt, 1986).

Accumulation zones of high-elevation alpine glaciers often contain well-preserved records of snowfall and provide an opportunity for retrieving climatic data. Recent studies on high-altitude alpine glaciers indicate that a variety of geochemical dating techniques can accurately and confidently delineate summer and winter layers within snow pits and snow/ice cores (Ambach and others, 1976; Jouzel and others, 1977; Oescheger and others, 1978; Oerter and others, 1982; Lyons and Mayewski, 1983; Holdsworth and others, 1984; Mayewski and others, 1984; Thompson and others, 1986; Yamada, 1987). A paleo-climatic record can be developed through an analysis of the chemical and physical characteristics of snow pits and ice cores. Identification of the seasonal variation of stable and radioactive isotopes, major ions, and microparticles has enabled researchers confidently to delineate seasonal snow-pack stratigraphy and to determine the rate of seasonal and annual snow accumulation. In addition, chemical records can usually be employed to determine the source of precipitation.

The basis of the snow-accumulation research in the Karakoram described in this paper is to employ glaciochemical dating techniques to examine the spatial and seasonal variations in accumulation. This is accomplished by developing a snow-pit sampling network covering a wide range of geographic locations within the Biafo Glacier basin, such a network type being essential for picking out altitudinal and lateral variations in snow accumulation.

Two previous studies have measured the rate of snow accumulation in the UIB. The Batura Glacier Investigation Group (1979) recorded a net winter accumulation of $1.03 \mathrm{~m}$ water equivalent (w.e.) at $4840 \mathrm{~m}$ on Batura Glacier $\left(36^{\circ} 40^{\prime} \mathrm{N}, 74^{\circ} 23^{\prime} \mathrm{W}\right)$. A stratigraphic analysis of ice layers in two different crevasse walls at $5000 \mathrm{~m}$ revealed an apparent net annual accumulation rate ranging from 1.03 to $1.25 \mathrm{~m}$ w.e. over the previous 5 years. Mayewski and others (1984) recovered a $16.6 \mathrm{~m}$ core from Sentik Glacier $\left(33^{\circ} 598^{\prime} \mathrm{N}, 75^{\circ} 57^{\prime} \mathrm{W}\right)$ in the Ladakh Himalaya at an elevation of $4908 \mathrm{~m}$. Core chronology was established by correlating a strong peak in the total $\beta$-activity time-series profile with the increased atmospheric concentration of total activity and B-activity following the 1963 series of thermonuclear weapons testing, as well as by seasonal signatures for selected chemical species and for deuterium The results indicated an average net accumulation of $0.62 \mathrm{~m}$ w.e. from 1963 to 1980.

\section{REGIONAL SETTING}

\section{Climatic controls}

Climate in the Karakoram is dominated by the influx of westerly air mases (Hewitt, 1968; Barry and Chorley, 1982). Throughout the winter the sub-tropical westerly jetstream steers cyclonic depressions toward the Karakoram 


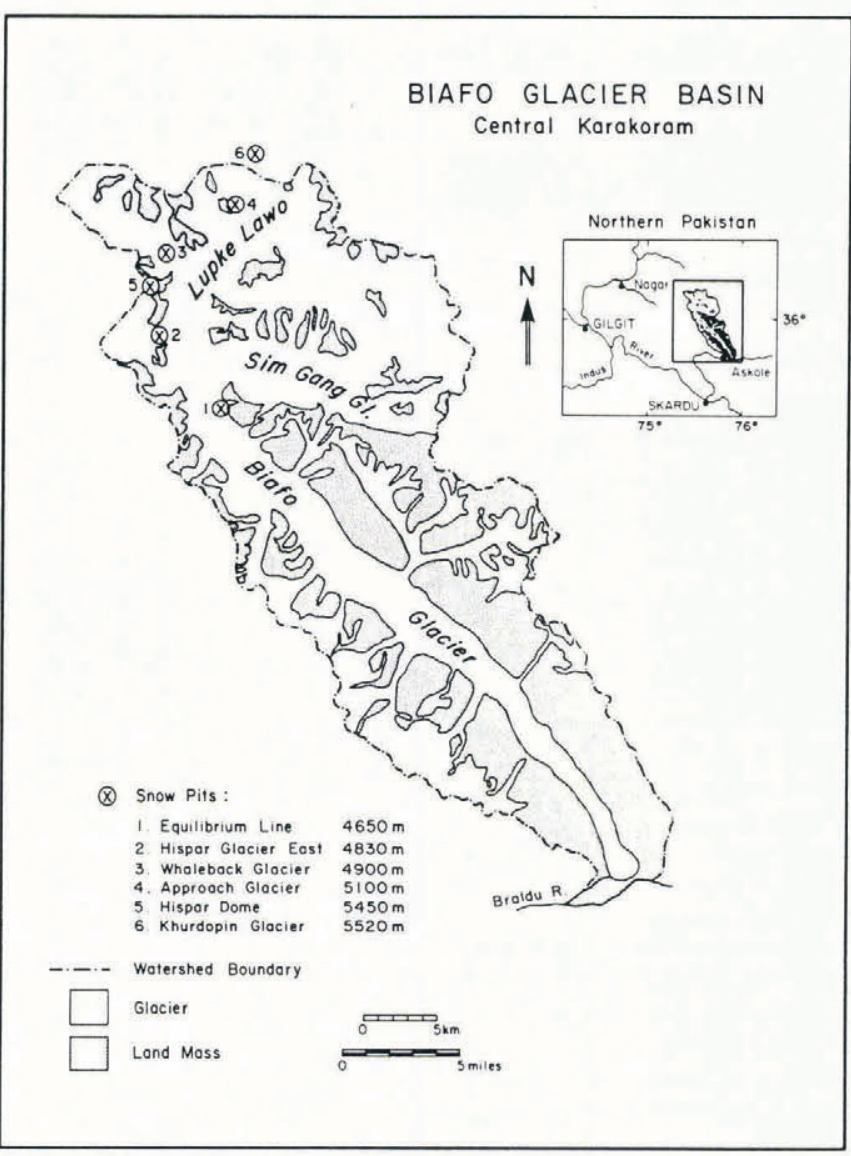

Fig. 1. The Biafo Glacier basin, central Karakoram.

and northern India. These lows penetrate across the Middle East from the Mediterranean Sea and the Atlantic Ocean. During the winter the jetstream is split into two distinct branches, one passing to the north and the other to the south of the Tibetan Plateau. In May and June the jetstream slowly weakens, and by mid-June is altogether diverted to the north of the plateau. While the regional airstream continues to be influenced by the westerlies, temporary destruction of the Tibetan anticyclone can result in the incursion of monsoonal air masses from the Indian Ocean into the Karakoram, resulting in heavy precipitation. We know from our own experience that significant amounts of snowfall can occur in the northern parts of the basin during the summer. Snowfall during late summer 1985 and 1986 exemplified the influx of monsoonal air masses.

\section{Study location: the Biafo Glacier basin}

Biafo Glacier descends south-west from the main crest of the Greater Karakoram in the central part of the range. The glacier itself is a large valley glacier about $59 \mathrm{~km}$ long, the basin has an area of $852 \mathrm{~km}^{2}$, of which $64 \%$ is covered by perennial snow and ice. A map of the Biafo Glacier basin, after Mott (1950), appears in Figure 1. The firn line in 1985 and 1986 lay at approximately $4650 \mathrm{~m}$ on Biafo Glacier (close to the location of the equilibrium-line snow pit illustrated in Figure 1). The glacier flows from a broad, gently sloping accumulation zone consisting of two large accumulation basins, Sim Gang Glacier to the west, and Lukpe Lawo to the north (Fig. 1). These basins are separated by steep, narrow ridges which occupy a small percentage of the area in the accumulation zone. The majority of precipitation falls on to the broad, relatively flat regions of the accumulation zone. Direct precipitation is the predominant form of nourishment. In this regard, Biafo Glacier appears to be exceptional amongst the valley glaciers in the central Karakoram. Thus, due to the minimal influence of avalanches on overall accumulation rates, the basin provides an ideal location for determining the rate of snow accumulation.

Khurdopin Glacier flows northward from the main crest of the Greater Karakoram. The glacier is approximately $47 \mathrm{~km}$ long. In general, basin morphology is similar to that of Biafo Glacier, although it is smaller.

\section{METHODOLOGY}

During the summer of 1986 we collected data from six snow pits, each 5-10 m deep (Table I), excavated in the accumulation zone of the Biafo Glacier and Khurdopin Glacier basins. All of the snow-pit locations were far from the influence of avalanches and experienced little or no heavy winds. There was no evidence of surface sastrugi nor of well-rounded snow grains on the surface, and wind conditions at all snow-pit locations were usually very calm. Fresh snow samples were also collected throughout the summer, and a $12 \mathrm{~m}$ record of snow accumulation, dating back to 1983, was obtained from the Hispar Dome site. The results and interpretation of these experimental data appears elsewhere (Wake, 1987).

Snow-pack stratigraphy was interpreted from measurements of density, hardness, color, crystal size, and shape, and the position of ice layers and debris bands. Snow samples were collected over an integrated section with a $1.5 \times 10^{-2} \mathrm{~m}$ vertical. Extreme care was exercised at all times during sample collection to ensure that samples were uncontaminated. A clean suit combined with an overthe-shoulder hood, particle mask, and plastic gloves, was worn by the sample collector. Samples were collected in pre-cleaned, $1.25 \times 10^{-1} \mathrm{~m}^{3}$ polypropylene containers with wide mouths and polyethylene caps. Following melting, the samples were transferred into two pre-cleaned linear polyethylene (LPE) scintillation vials each of $2 \times 10^{-2} \mathrm{~m}^{3}$ volume. In addition to the collection of samples described above, $3 \times 10^{-2} \mathrm{~m}$ samples were collected from the wall of the snow pit at the Hispar Dome site. These samples were melted and transferred into $5 \times 10^{-1} \mathrm{~m}^{3}$ LPE containers for total B-activity analysis.

\section{LABORATORY WORK}

Anions $\left(\mathrm{Cl}^{-}, \mathrm{SO}_{4}^{2-}\right.$ and $\left.\mathrm{NO}_{3}^{-}\right)$were analyzed using a Dionex model 2010 ion chromatograph with an AS-4 column with $0.0021 \mathrm{M} \mathrm{NaHCO}_{3} / 0.0017 \mathrm{M} \mathrm{Na}_{2} \mathrm{CO}_{3}$ eluent and a computer-driven autosampler. $\mathrm{Na}^{+}$was analyzed using a Perkin Elmer model 2280 atomic absorption spectrometer equipped with a Model 400 furnace. Both the anion and cation analyses were completed using the facilities of the Glacier Research Group at the University of New Hampshire. The oxygen-isotope analyses were done by the Geophysical Isotope Laboratory at the University of Copenhagen using gas-source mass spectrometry. A summary of the mean chemical content of the snow-pack at each sample location appears in Table I. Low minimum ion concentrations, especially for $\mathrm{Na}^{+}$and $\mathrm{Cl}^{-}$, demonstrate that field sampling and subsequent analytical procedures have not introduced significant levels of contamination. Analyses of sample blanks indicate that sample contamination during sample transfer and subsequent transport was negligible. Forty samples from the Hispar Dome snow pit were also analyzed for microparticle concentrations in 15 different size ranges, using a Coulter Counter TA III, by the Byrd Polar Research Center at Ohio State University. The total B-activity of samples recovered from the Hispar Dome site was measured at the University of New Hampshire using a Canberra model $2404 \alpha \beta \gamma$ counter with a $12 \mathrm{~h}$ counting period, on $47 \mathrm{~mm}$ Whatman SA-1 cation filters through which $5 \times 10^{-2} \mathrm{~m}^{3}$ samples had twice been gravity filtered.

\section{POST-DEPOSITIONAL ALTERATION}

The percentage of ice layers and lenses in each annual accumulation layer, expressed as annual melt per cent (AMP) ranged from 5 to $7 \%$ for the higher-elevation sites at $5450-5520 \mathrm{~m}$, and from 7 to $13 \%$ for the lower-elevation snow pits at $4650-5100 \mathrm{~m}$, indicating that melting events do occur. Herron and others (1981) found AMP values ranging from 3 to $8 \%$, excluding extreme melting events, in a deep core recovered from southern Greenland. Interpretation of glaciochemical data recovered from snow pits in which there has been melting, such as in the Karakoram, relies upon the conclusion that the redistribution of ions due to melt-water percolation is limited to the uppermost stratigraphic layers and is significantly less than seasonal 
Biafo Glacier basin

\begin{tabular}{|c|c|c|c|c|c|c|}
\hline & $\begin{array}{l}\text { Equilibrium } \\
\text { line }\end{array}$ & $\begin{array}{l}\text { Hispar } \\
\text { Glacier E. }\end{array}$ & $\begin{array}{c}\text { Whaleback } \\
\text { Glacier }\end{array}$ & $\begin{array}{c}\text { Approach } \\
\text { Glacier }\end{array}$ & $\begin{array}{l}\text { Hispar } \\
\text { Dome }\end{array}$ & $\begin{array}{c}\text { Kurdopin } \\
\text { Glacier }\end{array}$ \\
\hline Elevation (m) & 4650 & 4830 & 4900 & 5100 & 5450 & 5520 \\
\hline Aspect & SW & E & SE & E & - & W \\
\hline Depth (m) & 2.3 & 4.8 & 4.5 & 4.8 & 5.0 & 10.0 \\
\hline No. of samples & 16 & 33 & 20 & 40 & 41 & 73 \\
\hline Density* & 415 & 470 & 490 & 535 & 450 & 470 \\
\hline$\delta^{18} \mathrm{O}$ & -14.0 & -14.5 & -18.1 & -17.2 & -13.0 & -16.2 \\
\hline $\mathrm{Na}^{+}: \mathrm{Cl}^{-}$ & 0.41 & 0.65 & - & 0.51 & 0.46 & 0.56 \\
\hline $\mathrm{Na}^{+\dagger}$ & 17 & 33 & 9 & 16 & 13 & 37 \\
\hline $\mathrm{Cl}^{-}+$ & 40 & 50 & - & 19 & 28 & 50 \\
\hline $\mathrm{NO}_{3}^{-\dagger}$ & 218 & 224 & - & 96 & 154 & 167 \\
\hline $\mathrm{SO}_{4}^{z^{3}+}$ & 143 & 121 & - & 47 & 82 & 128 \\
\hline
\end{tabular}

* Mean values for each snow pit in $\mathrm{kg} / \mathrm{m}^{3}$.

Mean values for each snow pit in $\mu \mathrm{g} / \mathrm{kg}$.

accumulation. This conclusion is derived from two separate lines of evidence:

First, snow-pack temperature is below freezing slightly beneath the air-snow interface. Upon encountering a below-freezing layer, melt water percolating down through the snow-pack spreads out laterally and freezes, forming ice layers and lenses. The ice layers thus formed can then act as a barrier to further melt-water percolation. The presence of ice layers at between 20 and $60 \mathrm{~cm}$ (one-tenth to one-third of annual snow depth) in all of the snow pits analyzed delineates the maximum depth to which melt water percolates. The AMP values indicate that more melt water is generated at the lower-elevation sites. Therefore, confidence in the above-stated conclusion increases with increasing elevation of the sample site.

Secondly, the chemical profiles from a snow-pack in which there had been significant melt-water percolation would display $\delta^{18} \mathrm{O}$ and ion time-series profiles that appeared washed out and show weak, if any, seasonal variation (Mayewski and others, 1981). The $\delta^{18} \mathrm{O}$ and ion time-series profiles from all of the sample sites show distinct seasonal variations, and thus do not appear to have been affected significantly by melt-water percolation (Fig. 2A and B).

\section{SNOW-PIT DATA}

A summary of the chemical and physical data for each snow pit appears in Table I. The time-series profiles of the chemical components $\left(\delta^{18} \mathrm{O}\right.$, sodium, chloride, sulfate, nitrate ions, and total $\beta$-activity) and of the physical properties (microparticle concentrations, the stratigraphic position of the ice, and visible dirt layers) for the high-elevation sites $(5450$ and $5520 \mathrm{~m}$ ) appear in Figure 2.

\section{Oxygen isotopes}

The oxygen-isotope record is considered to be the single most useful profile, as it consistently displays a regular pattern of seasonal variations. Winter precipitation is characterized by a relative depletion in the heavy isotope, which results in an increasingly negative $\delta^{18} \mathrm{O}$ value, summer precipitation is characterized by a relative increase in the heavy isotope content, which results in a less negative $\delta^{18} \mathrm{O}$ value (Dansgaard and others, 1973). Distinct changes in the oxygen-isotope profiles were used as reference horizons to define summer and winter strata in all of the snow pits.

\section{Sodium and chloride ions}

Variations in $\mathrm{Na}^{+}$and $\mathrm{Cl}^{-}$concentrations with depth are closely related, correlation coefficients for each snowpit are respectively $0.92,0.61,0.73,0.71$, and 0.81 at the 0.001 significance level. The mean $\mathrm{Na}^{+}: \mathrm{Cl}^{-}$ratio for all samples from the Karakoram is 0.54 , very close to the ratio for
A HISPAR DOME $5450 \mathrm{~m}$

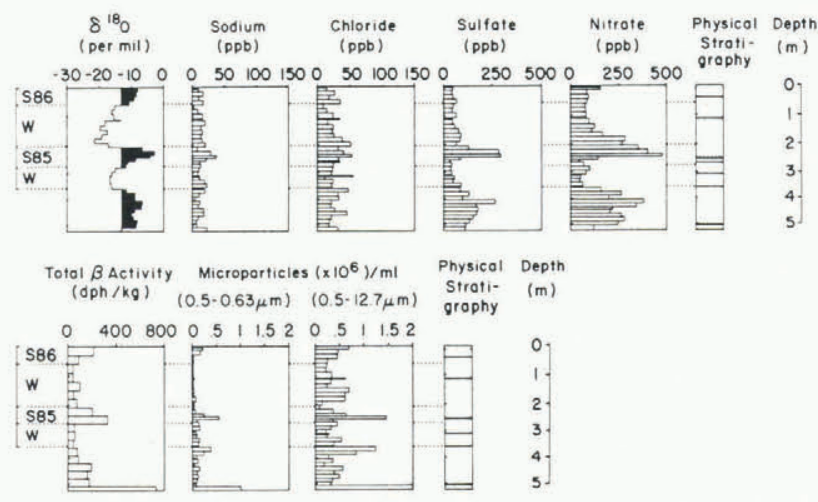

B KHURDOPIN GLACIER $5520 \mathrm{~m}$

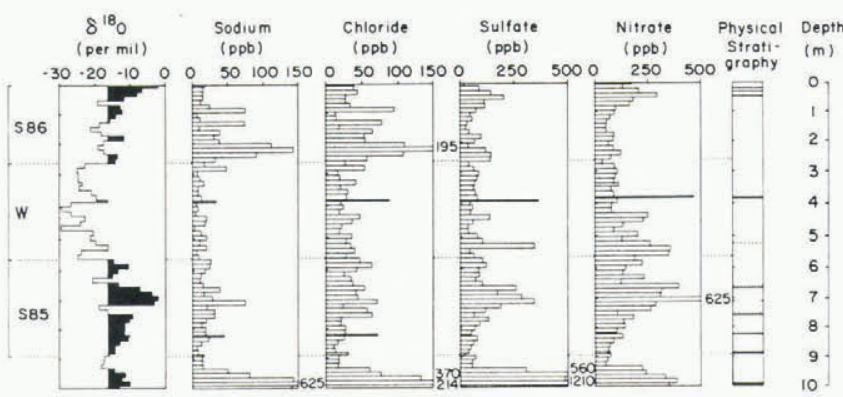

Fig. 2. $\delta^{18} \mathrm{O}$ and ion time-series profiles for Hispar Dome (A) and Khurdopin Glacier (B).

sea-water which is 0.56 . This strongly suggests a marine source for most of the $\mathrm{Na}^{+}$and $\mathrm{Cl}^{-}$within the central Karakoram snow-pack. The $\mathrm{Na}^{+}$and $\mathrm{Cl}^{-}$time series from Khurdopin Glacier (Fig. 2) show strong seasonal variations, with peaks in the profiles corresponding to less negative summer $\delta^{18} \mathrm{O}$ values. The $\mathrm{Na}^{+}$and $\mathrm{Cl}^{-}$profiles from Hispar Dome (Fig. 2) display weaker seasonal variations, although the higher values also correspond to summer deposition Interpretations by Mayewski and others (1984) suggest that the high concentrations of $\mathrm{Na}^{+}$and $\mathrm{Cl}^{-}$observed in the time-series profiles from a core recovered in the Ladakh Himalaya are due to moisture derived from the Arabian Sea. The increased levels of these ions observed in the time-series profiles from the Karakoram coincide with summer strata, and also most probably reflect the influx of moisture from the Arabian Sea. Winter layers, as defined by the ${ }^{18} \mathrm{O}$ profile, are characterized by relatively low values 
TABLE II. COMPARISON OF CHEMICAL CONTENT IN SNOW FROM THE KARAKORAM AND LADAKH HIMALAYA

\section{Biafo Glacier Karakoram}

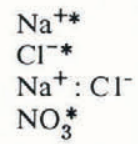

24

38

0.54

178

Sentik Glacier Ladakh Himalaya ${ }^{\dagger}$

\section{2 \\ 104 \\ 62}

*Mean values for all samples collected, in $\mu \mathrm{g} / \mathrm{kg}$.

Lyons and Mayewski (1983) and Mayewski and others (1984).

for $\mathrm{Na}^{+}$and $\mathrm{Cl}^{-}$. Low winter concentrations are attributed to westerly marine sources more distant than the Arabian Sea, most probably the Atlantic Ocean or the Mediterranean Sea. Mean concentrations of $\mathrm{Na}^{+}$and $\mathrm{Cl}^{-}$from the central Karakoram are three to four times lower than those measured in the Ladakh Himalaya (Table II). This difference suggests that westerly derived moisture, with its lower $\mathrm{Na}^{+}$and $\mathrm{Cl}^{-}$content, has a greater influence on precipitation in the Karakoram than in the Ladakh Himalaya.

\section{Sulfate and nitrate ions}

It is apparent in the time-series profiles from the high-elevation sites (Fig. 2) that $\mathrm{SO}_{4}^{2-}$ and $\mathrm{NO}_{3}^{-}$concentrations display strong seasonal variation; high concentrations correspond to mid- to late-summer strata. Several studies have identified specific sources of sulfate ions in Greenland snow (Herron, 1982; Mayewksi and others, 1986). Sea-salt-associated $\mathrm{SO}_{4}^{2-}$ (Blanchard, 1983) and biogenic $\mathrm{SO}_{4}^{2-}$ originating from the oceans (Bonsang and others, 1980) represents less than $15 \%$ of total $\mathrm{SO}_{4}^{2-}$ in snow from the Karakoram. The random nature of volcanic events cannot account for the observed seasonal variations in the concentration record. India is the closest source of anthropogenically produced $\mathrm{SO}_{4}^{2-}$ and these excess ions could be transported into the Karakoram during the summer at the same time as moisture derived from the Arabian Sea is drawn into the region. Terrestrial biogenic emissions are a source of both excess $\mathrm{SO}_{4}^{2-}$ and excess $\mathrm{NO}_{3}^{-}$, and are therefore discussed together below. A variety of different sources for $\mathrm{NO}_{3}^{-}$and $\mathrm{NO}_{2}^{-}$ions in the Ladakh Himalaya has been reviewed by Lyons and Mayewski (1983). Seasonally controlled biological emissions in the Karakoram could account for the observed seasonal variation in the $\mathrm{SO}_{4}^{2-}$ and $\mathrm{NO}_{3}^{-}$profiles. Both sulfur and nitrogen are injected into the atmosphere by biological emissions, primarily from plant exudates (Lawson and Winchester, 1979; Stallard and Edmond, 1981). Nitrogen gases are also readily liberated from the soil during the warm season (Yaalon, 1964). The extensive use of natural fertilizer during the summer is a potential seasonal source of nitrate. In addition locally derived pollution, predominantly from biomass combustion, is a potential source of both $\mathrm{SO}_{4}^{2-}$ and $\mathrm{NO}_{3}^{-}$. The mean concentration of the samples from the Karakoram is almost three times the mean combined $\mathrm{NO}_{2}^{-} / \mathrm{NO}_{3}^{-}$concentration of the Sentik Glacier core samples (Table II).

\section{Total $\beta$-activity}

The total $\beta$-activity profile from Hispar Dome (Fig. 2) also displays strong peaks within summer deposits. Spring precipitation is characterized by high values of total B-activity (Ambach and others, 1976). Ablation horizons act as adsorption filters and are characterized by concentrated $\beta$-active deposits, even during periods of low atmospheric fall-out (Prantl and others, 1973; Ambach and others, 1976). The strong summer peaks in the total B-activity profile from the Hispar Dome site support this model.

\section{Microparticles}

The small $(0.5-0.63 \mu \mathrm{m})$ and total $(0.5-12.7 \mu \mathrm{m})$ microparticle profiles from the Hispar Dome site display seasonal variations similar to those already described, with typically sharp peaks occurring in the summer horizons. Seasonal variations in the total microparticle profile correlate well with variations in the total B-activity profile, suggesting that microparticles could be acting as adsorption filters for radionuclides. Unfortunately, the record is too short for the development of concrete conclusions at this time.

\section{Physical stratigraphy}

In the four low-elevation snow pits $(4650-5100 \mathrm{~m})$ the end of the 1985 summer season is clearly identified by a horizon containing visible dirt adjacent to an ice layer. Visible dirt layers occur nowhere else in the profiles. This is a strong indication that physical characteristics of the snow-pack at elevations ranging from 4650 to $5100 \mathrm{~m}$ can be good stratigraphic indicators for the most recent year of snow accumulation. This increases confidence in the results of the two snow pits investigated in 1985 (Young and others, 1986).

\section{SPATIAL VARIATION OF SNOW ACCUMULATION}

Distinct changes in the $\delta^{18} \mathrm{O}$ profile are used as reference horizons to define summer and winter strata in all of the snow pits. Seasonal cycles that are not clear from the $\delta^{18} \mathrm{O}$ profile can be clarified through an analysis of profiles of the major ions, total $\beta$-activity, and microparticles. The seasonal snow-accumulation data, in metres of water equivalent, for the 1985-86 accumulation year appear in Table III, and these results provide the basis for the interpretation of the altitudinal and lateral variation of snow accumulation within the central Karakoram.

TABLE III. ALTITUDINAL VARIATION OF SNOW ACCUMULATION IN THE BIAFO GLACIER BASIN, 1985-86

Site

Elevation Net annual Net summer accumulation accumulation

(m) (m w.e.)

Equilibrium line 4650

0.90

Hispar Glacier E.

4830

1.07

31

Whaleback Glacier

4900

1.79

$5100 \quad 1.88$

49

Approach Glacier

5450

1.20

27

Hispar Dome

\section{Altitude variation of snow accumulation}

The study sites within the Biafo Glacier basin can be separated into three distinct groups which represent three elevation bands (Table III). Maximum accumulation in the Biafo Glacier basin occurs in the elevation band from $4900 \mathrm{~m}$ up to at least $5100 \mathrm{~m}$. This band may extend as high as $5400 \mathrm{~m}$ a.s.l.; unfortunately, no data were collected at these elevations. Many sources, including Flohn (1974), Barry (1981), and Price (1981), have identified an increase in the amount of precipitation with altitude in temperate and sub-tropical mountain ranges throughout the world, and this phenomenon is apparent in the Karakoram. However, a second very important process, involving change in the pattern of snow deposition due to the action of the wind, must also be considered.

The zone of maximum accumulation from $4900 \mathrm{~m}$ to $5400 \mathrm{~m}$ coincides perfectly with the broad, open areas in the accumulation zone of Biafo Glacier, which accounts for the bulk of glacier cover in the basin. The strong relationship between snow accumulation and basin morphology suggests that a part of the snow accumulation in the elevation range from 4900 to $5400 \mathrm{~m}$ is due to the redistribution of snow by strong winds, both during precipitation and following deposition. This is most likely to be a function of strong winds at high altitude, especially those accelerating over peaks and ridges keeping snow in suspension, while the relatively sheltered, deeper air column over the broad, flat areas of the accumulation zone acts to 
trap snow. Morphologically, the accumulation zone of Khurdopin Glacier is much like Lukpe Lawo, but on a smaller scale and at a higher elevation. Data from the Khurdopon Glacier snow pit at $5520 \mathrm{~m}$ indicate an annual rate of snow accumulation of $2.31 \mathrm{~m}$ w.e. within the broad flat areas of the accumulation zone.

\section{Lateral variation of snow accumulation}

The data presented in Table III suggest that accumulation for any given elevation band within the broad, flat areas in the accumulation zone of Biafo Glacier is relatively uniform. Moreover, this is also a good indication that within any elevation band the snow-pit locations chosen may be considered to provide a representative sample for the whole basin, in the sense that none seems subject to major disturbances by wind or avalanches. So long as samples of net annual accumulation can be obtained which measure or predict average basin accumulation by elevation, we can ultimately determine large-scale overall variations in accumulation, as opposed to small-scale local variations.

With this stratified view of snow accumulation in the accumulation zone of the Biafo Glacier basin, a crude estimate of the moisture input during the 1985-86 accumulation year can be calculated (Table IV). Snow-pit data exist for three of the seven elevation bands, and these three elevation bands represent $75 \%$ of the glacier-covered area in the accumulation zone. Moisture input into the glacierized part of the accumulation zone of Biafo Glacier is estimated to be of the order of $0.5 \mathrm{~km}^{3}$ of water, representing an annual yield of $1.35 \mathrm{~m}$ w.e. (note that these figures do not include estimates of snow falling below the equilibrium line). This is almost three times as large as the annual yield of $0.50 \mathrm{~m}$ w.e. which flows past the Besham Qila gauging station (Pipes and Quick, 1987) about $40 \mathrm{~km}$ up-stream from the Tarbela reservoir. Accepting the relatively crude method of estimation, these results are promising and provide us with a rough framework from which we can begin to quantify the various components of the hydrological system in the Biafo Glacier basin. Possession of such a framework represents a crucial step towards a better understanding of snow and ice hydrology in the UIB.

\section{CONCLUSIONS}

Net annual accumulation has been determined at six different sites in the central Karakoram through an analysis of the chemical and physical characteristics of the snowpack. The results demonstrate that glaciochemical investigations are a precise and efficient method by which to determine net seasonal snow accumulation in the Karakoram. Especially importantly in regions for which little data exist, this technique makes possible the production of snow accumulation and chemical records for use in both climatic and hydrological investigations. In addition, the chemical records provide valuable data concerning sources of moisture.

The results shown in Tables III and IV provide information about a number of different aspects of snow accumulation in the central Karakoram. Within the Biafo Glacier basin, maximum accumulation occurs in the elevation band from 4900 to $5400 \mathrm{~m}$ a.s.l. and this zone probably extends as high as $5500 \mathrm{~m}$ a.s.1. in the Khurdopin Glacier basin. The altitudinal variation of snow accumulation within the central Karakoram is best explained by an increase in precipitation with elevation combined with the redistribution of snow by strong winds. Snow redistribution by the wind probably results in an overcatch situation within the broad, protected areas of the accumulation zone. The elevation over which winds redistribute snow is dependent upon the area-altitude relationships of the glacier basin.

For any given band, accumulation of the broad flat parts of the accumulation zone in the Biafo Glacier basin is relatively uniform. This is a good indication that the locations chosen for the snow pits within the basin are representative of the basin in general. Moisture input in the accumulation zone of Biafo Glacier for the 1985-86 season was estimated to be $0.5 \mathrm{~km}^{3}$. As this figure does not include snow falling below the equilibrium line, it does not
TABLE IV. ESTIMATE OF MOISTURE INPUT IN THE GLACIERIZED PART OF THE ACCUMULATION ZONE IN THE BIAFO GLACIER BASIN, 1985-86

\begin{tabular}{|c|c|c|}
\hline $\begin{array}{l}\text { Elevation } \\
\text { band }\end{array}$ & Area & $\begin{array}{r}\text { Net annual } \\
\text { accumulation }\end{array}$ \\
\hline
\end{tabular}

$\left(\mathrm{km}^{2}\right) \quad$ (m w.e.)

$\begin{array}{lr}4650-4877^{*} & 63.0 \\ 4877-5181^{*} & 109.5 \\ 5181-5486^{*} & 99.2 \\ 5486-5791 & 61.8 \\ 5791-6096 & 27.6 \\ 6096-6401 & 8.6 \\ 6401-6706 & 1.3\end{array}$

$\begin{array}{lr}1.0 & 84 \\ 1.9 & 208 \\ 1.9 & 188 \\ 1.2(?) & 74 \\ 1.2(?) & 33 \\ 1.2(?) & 10 \\ 1.2(?) & 2\end{array}$

Totals

371.0

599

*Elevation bands for which snow-accumulation data exist.

represent total moisture input to the whole basin. Annual yield for moisture input into the accumulation zone of the Biafo Glacier basin was equivalent to $1.35 \mathrm{~m}$ w.e.

\section{ACKNOWLEDGEMENTS}

I thank K. Hewitt for providing me with the opportunity to work in the Karakoram, and gratefully acknowledge the contribution of P.A. Mayewski, M.J. Spencer, and M.S. Twickler in providing valuable guidance during the preparation and laboratory phases of this research. Expedition members included B. Roberts, C. David, S. Khan, R. Shah, Hussain, and Mohammed. W. Dansgaard and N. Gundrestrup kindly conducted the oxygen-isotope analyses. L. Thompson graciously provided the microparticle analyses. The figures were drafted by S. Palmer. This research was undertaken as part of the Snow and Ice Hydrology Project, which is a collaborative project funded jointly by the Canadian International Development Research Centre, the Water and Power Development Authority in Pakistan, and Wilfrid Laurier University, Waterloo, Canada.

\section{REFERENCES}

Ambach, W., and 6 others. 1976. Deuterium, tritium and gross-beta-activity investigations on Alpine glaciers (Ötztal Alps). J. Glaciol., 17(77), 383-400.

Barry, R.G. 1981. Mountain, weather and climate. London and New York, Methuen.

Barry, R.G. and R.J. Chorly. 1982. Atmosphere, weather and climate. Fourth edition. London and New York, Methuen.

Batura Glacier Investigation Group. 1979. The Batura Glacier in the Karakoram Mountains and its variations. Sci. Sin., 22, 958-974.

Blanchard, D.C. 1983. The production, distribution and bacterial enrichment of the sea salt aerosol. In Liss, P.S. and W.G.N. Slinn, eds. Air-sea exchange of gases and particles. Hingman, MA, Reidel, 402-454.

Bonsang, B., B.C. Nguyen, A. Gaudry, and G. Lambert. 1980. Sulfate enrichment in marine aerosols owing to biogenic gaseous sulfur compounds. J. Geophys. Res., 85(C12), 7410-7416.

Butz, D. and K. Hewitt. 1986. A note on the upper Indus basin weather stations. In Hewitt, $\mathrm{K}$., ed. Snow and Ice Hydrology Project - Annual Report and Scientific Papers, 1985. Waterloo, Ontario, Wilfrid Laurier University, 64-76.

Dansgaard, W., S.J. Johnson, H.B. Clausen, and N. Gundestrup. 1973. Stable isotope glaciology. Medd. Gronl., 197(2).

Flohn, H. 1974. Contribution to a comparative meteorology of mountain areas. In Ives, J.D. and R.G. Barry, eds. Arctic and alpine environments. London, Methuen, 55-71. 
Herron, M.M. 1982. Impurity sources of $\mathrm{F}^{-}, \mathrm{Cl}^{-}, \mathrm{NO}_{3}{ }^{-}$and $\mathrm{SO}_{4}{ }^{2-}$ in Greenland and Antarctic precipitation. $J$. Geophys. Res., 87(C4), 3052-3060.

Herron, M.M., S.L. Herron, and C.C. Langway, jr. 1981. Climatic signal of ice melt features in southern Greenland. Nature, 293(5831), 389-391.

Hewitt, K. 1986. The upper Indus snow belts: snowfall and sources of water yield. In Hewitt, K., ed. Snow and Ice Hydrology Project - Annual Report and Scientific Papers, 1985. Waterloo, Ontario, Wilfrid Laurier University, 58-63.

Hewitt, K. Unpublished. Studies in the geomorphology of the upper Indus basin. (Ph.D. thesis, University College, London, 1968.)

Holdsworth, G., M. Pourchet, F.A. Prantl, and D.P. Meyerhof. 1984. Radioactivity levels in a firn core from the Yukon Territory, Canada. Atmos. Environ., 18(2), 461-466.

Jouzel, J., L. Merlivat, and M. Pourchet. 1977. Deuterium, tritium, and $B$ activity in a snow core taken on the summit of Mont Blanc (French Alps). Determination of the accumulation rate. J. Glaciol., 18(80), 465-470.

Lawson, D.R. and J.W. Winchester. 1979. Sulfur, potassium and phosphorus associations in aerosols from South American tropical rain forests. J. Geophys. Res., 84(C7), 3723-3727.

Lyons, W.B. and P.A. Mayewski. 1983. Nitrate plus nitrite concentrations in a Himalayan ice core. Geophys. Res. Lett., 10(12), 1160-1163.

Mayewski, P.A., W.B. Lyons, and N. Ahmad. 1981. Reconnaissance glaciochemistry studies in the India Himalaya. Proc. East. Snow Conf., 38, 45-48.

Mayewski, P.A., W.B. Lyons, N. Ahmad, G. Smith, and M. Pourchet. 1984. Interpretation of the chemical and physical time-series retrieved from Sentik Glacier, Ladakh Himalaya, India. J. Glaciol., 30(104), 66-76.

Mayewski, P.A., and 7 others. 1986. Sulfate and nitrate concentrations from a south Greenland ice core. Science, 232(4753), 975-977.

Mercer, J.H. 1975. Glaciers of the Karakoram. In Field, W.O., ed. Mountain glaciers of the Northern Hemisphere. Vol. 1. Hanover, NH, Cold Regions Research and Engineering Laboratory, 371-409.

Mott, P.G. 1950. Karakoram survey, 1939. A new map. Geogr. J., 116(1-3), 89-95.
Oerter, H., O. Reinwarth, and H. Rufli. 1983. Core drilling through a temperate Alpine glacier (Vernagtferner, Oetztal Alps) in 1979. Z. Gletscherkd. Glazialgeol., 18(1), 1982, $1-11$.

Oeschger, H., B. Stauffer, W. Haeberli, and H. Röthlisberger. 1978. First results from Alpine core drilling projects. Z. Gletscherkd. Glazialgeol., 13(1-2), 1977, 193-208.

Pipes, A. and M. Quick. 1987. Assessment of forecasting system for the UIB. In Hewitt, K., ed. Snow and Ice Hydrology Project - Annual Report, 1986. Waterloo, Ontario, Wilf rid Laurier University.

Prantl, F.A., W. Ambach, and H. Eisner. 1973. Alpine glacier studies with nuclear methods. International Association of Scientific Hydrology Publication 107 (Banff symposia 1972 - The Role of Snow and Ice in Hydrology), 435-444.

Price, L.W. 1981. Mountains and man: a study of processes and environment. Berkley, University of California Press.

Stallard, R.F. and J.M. Edmond. 1981. Geochemistry of the Amazon. 1. Precipitation chemistry and the marine contribution to the dissolved load at the time of peak discharge. J. Geophys. Res., 86(C10), 9844-9858.

Thompson, L.G., E. Mosley-Thompson, W. Dansgaard, and P.M. Grootes. 1986. The Little Ice Age as recorded in the stratigraphy of the tropical Quelccaya ice cap. Science, 234(4774), 361-364.

Wake, C. 1987. Snow accumulation studies in the central Karakoram. Proc. East. Snow Conf., 44, 19-33.

Wake, C. Unpublished. The spatial and temporal variation of snow accumulation in the central Karakoram, northern Pakistan. (M.A thesis, Wilf rid Laurier University, 1987.)

Yaalon, D.H. 1964. The concentration of ammonia and nitrate in rain water over Israel in relation to environmental factors. Tellus, 16(2), 200-204.

Yamada, T. 1987. Glaciological characteristics revealed by 37.6-m deep core drilled at the accumulation area of San Rafael Glacier, the northern Patagonia icefield. Bull. Glacier Res., 4, 59-67.

Young, G., K. Hewitt, and C. Wake. 1986. Snow stratigraphy in the accumulation zones of the Biafo and Hispar glaciers. In Hewitt, K., ed. Snow and Ice Hydrology Project - Annual Report and Scientific Papers, 1985. Waterloo, Ontario, Wilfrid Laurier University, 170-179. 